\title{
Differences and Similarities between Coaching, Instructional and Educational Leadership Styles
}

\author{
Agnè Daučianskaité - Vilma Žydžiūnaite $\dot{e}^{*}$ \\ Received: July 1, 2020; received in revised form: August 29, 2020; \\ accepted: September 2, 2020
}

\begin{abstract}
:
Introduction: Leadership is part of the educational process, nevertheless, it has not been fully surveyed. Successful teaching and good results usually depend on an educator, as well as on the way s/he organizes the educational process. There are a lot of various educators who organize the educational process in a different way. As a result of that, three prevailing leadership styles appear - coaching, instructional and educational. In the scientific literature, it is possible to find a huge amount of information about these three styles, however, little research has been carried on the comparison of differences and similarities between them. Therefore, the purpose of this research is to derive and compare parameters (criteria) in leadership, distinguishing and summarizing their differences and similarities in tables.

Purpose: The purpose of the paper is to compare the particular leadership styles according to formulated original parameters (criteria).

Methods: In the paper, the method of a comparative literature review is applied.

Conclusion: Comparing leadership styles, coaching leadership is focused on helping the learner and the improvement of the educational process; instructional leadership aims for effective and academic teaching when the educator is the leader; while educational leadership is focused on distributing education when the teacher, student and school environment are involved in the educational process.
\end{abstract}

Key words: coaching leadership, educational leadership, differences, similarities, instructional leadership.

\footnotetext{
* Agnè Daučianskaitè, Vytautas Magnus University, Academy of Education, Educational Research Institute, Kaunas, Lithuania; daucianskaite.agne@gmail.com Vilma Žydžiūnaite, Vytautas Magnus University, Academy of Education, Educational Research Institute, Kaunas, Lithuania; vilma.zydziunaite@vdu.lt
} 


\section{Acta Educationis Generalis \\ Volume 10, 2020, Issue 3}

\section{Introduction}

Leadership is important in education, not only influencing the learner's results and the relationship between educator and learner, but also seeking to maintain a good learning atmosphere, develop personality in a broad sense, develop teamwork perspectives, improve the educational process, and strengthen the school leader's and teacher's education. According to Harris (2005), teacher leadership is important for school performance and change, as well as student achievement. Nowadays a plethora of educators use a variety of leadership strategies, but all this is like a hidden form. First, there are educators who help learners to achieve learning results and tend to provide the educational process in a facilitated form. Second, there are teachers who strive to reach learning achievements through rigorous training and respect only their own opinion. Third, there are educators who place more emphasis on both - their own and the student's opinion, allowing them to choose and understand which opinion is more important. As a result, such leadership styles as coaching, instructional and educational emerge. It is coaching leadership that is characterized by help for the learner, learner's confidence in the educator, and a warm relationship with the educator in the learning process, which influence further career success (Berg \& Karlsen, 2007; Robertson, 2008). Instructive leadership is characterized by the educator's leadership in the educational process, effective teaching and the pursuit of higher results. It also seeks a relationship that is established not only with the learner but also with the learner's environment (Goldring et al., 2009; Leithwood et al., 2010; Hallinger, 2011). Educational leadership is characterized by cooperation in the educational process, that is, when the educator and the learner pursue common educational goals and outcomes (Mulford \& Silins, 2003; Murphy et al., 2007).

There is much research done internationally on coaching, instructional and educational leadership styles, which is why it is not a new phenomenon (Hajisoteriou, 2012; Hallinger, Piyaman et al., 2017).

Meanwhile, research on leadership, school leadership, its concept and types has been conducted in Lithuania by Talalienè and Šečkuvienè (2015), but their comparison is based on descriptive analysis. Nevertheless, separate research, both in Lithuania and internationally, on the differences and similarities between coaching, instructional and educational leadership styles is still lacking. In scientific research there is much general information, repetitive, but this is not structured according to parameters (criteria), which would reflect education and learning. The purpose of this research is to compare the particular leadership styles according to formulated original parameters (criteria). This scientific article is based on a comparative literature review. 


\section{Acta Educationis Generalis \\ Volume 10, 2020, Issue 3}

\section{Methodology}

The sources of scientific literature were selected according to these significant concepts: leadership, leadership styles, leadership style, coaching leadership, educational leadership, instructional leadership, types of leadership styles, differences and similarities between coaching, instructional and educational leadership, the styles of coaching, instructional and educational leadership. Performing the research of scientific literature, 45 scientific sources were analyzed: out of these, 1 national and 44 international scientific literature sources were investigated.

To perform the research on the differences and similarities of coaching, instructional and educational leadership styles, the method of comparative theoretical analysis was chosen. According to Miethe and Drass (1999) comparative analysis is used in macro social research. Meanwhile, other scientists name this analysis macroscopic comparative analysis (Leech \& Onwuegbuzie, 2008). Qualitative comparative analysis involves a systematic analysis of similarities and differences of particular concepts within the research problem (Miethe \& Drass, 1999). The purpose of presented matrixes are to reveal comparisons based on criteria (Chen, 2016). Therefore, in this study, the parameters (criteria) of each leadership style were singled out, according to which the essential features of each style were described. In the table, the data were systematized until the information was repeated. Then comparative groups, in this case parameters (criteria), searching for commonalities, allowed to simplify, identify and remove unnecessary variables from the table (Miethe \& Drass, 1999). Performing a theoretical comparative analysis, the following criteria were identified for differences in such leaderships styles as: goal, implementation of the educational process/teaching methodologies, leader's activity, educator's activity, learner's results, learning environment, relationships in leaderships, teamwork, educator's professional development and personal features, advantages and disadvantages. Identification of such similarities of leadership criteria as factors that determine success in the educational process, learning environment, learning process outcomes, feedback, and similar benefits of leadership then followed.

\section{Results}

\subsection{Differences between coaching, instructional and educational leadership styles}

Literature review of differences between coaching, instructional and educational leadership styles revealed that each of these styles has such parameters (criteria) as: goal, implementation of educational process/teaching methodologies, leader's activity, educator's activity, student's activity, student's results, learning environment, relationship in leadership, teamwork, 


\section{Acta Educationis Generalis \\ Volume 10, 2020, Issue 3}

educator's professional development and personal features, advantages and disadvantages.

Table 1

Differences between coaching, instructional and educational leadership styles

\begin{tabular}{|c|c|c|c|}
\hline Criterion & $\begin{array}{c}\text { Coaching } \\
\text { leadership/Authors }\end{array}$ & $\begin{array}{c}\text { Instructional } \\
\text { leadership/Authors }\end{array}$ & $\begin{array}{c}\text { Educational } \\
\text { leadership/Authors }\end{array}$ \\
\hline Goal & $\begin{array}{l}\text { Help the educator } \\
\text { to improve and } \\
\text { achieve goals (Berg } \\
\& \text { Karlseno, 2007). }\end{array}$ & $\begin{array}{l}\text { Encourage the } \\
\text { learner to } \\
\text { understand and } \\
\text { recognize effective } \\
\text { learning, and the } \\
\text { educator should be } \\
\text { able to improve } \\
\text { students' learning } \\
\text { having a } \\
\text { conversation } \\
\text { (Hallinger, 2011). }\end{array}$ & $\begin{array}{l}\text { Create the } \\
\text { conditions for } \\
\text { distribution } \\
\text { leadership in } \\
\text { education (Male } \\
\text { \& Palaiologou, } \\
\text { 2015). }\end{array}$ \\
\hline $\begin{array}{l}\text { Implementation } \\
\text { of educational } \\
\text { process }\end{array}$ & $\begin{array}{l}\text { - Providing new } \\
\text { tasks and } \\
\text { maximizing them } \\
\text { (Robertson, 2008). } \\
\text { - } \quad \text { Right time } \\
\text { planning of the } \\
\text { educational process } \\
\text { (Bean et al., 2010). } \\
\text { - Effective training } \\
\text { (Eriksen et al., } \\
\text { 2020). }\end{array}$ & $\begin{array}{l}\text { - Emphasis on } \\
\text { curriculum and } \\
\text { teaching (Smith \& } \\
\text { Andrews, 1989). } \\
\text { - Effective modeling } \\
\text { of training } \\
\text { (Southworth, } \\
\text { 2009). }\end{array}$ & $\begin{array}{l}\text { - Continuous } \\
\text { accumulation of } \\
\text { knowledge } \\
\text { (Murphy et al., } \\
\text { 2007). } \\
\text { - Systematization } \\
\text { of learning } \\
\text { experiences } \\
\text { (Hart, 1999). }\end{array}$ \\
\hline $\begin{array}{l}\text { Manager's } \\
\text { activity }\end{array}$ & $\begin{array}{l}\text { Manage activities, } \\
\text { human resources, } \\
\text { behavior of } \\
\text { relationship and } \\
\text { systematize } \\
\text { everything } \\
\text { (Turnern, 2010). } \\
\text { - Strengthen work, } \\
\text { develop internal } \\
\text { trust and } \\
\text { communication } \\
\text { (Pousa \& Mathieu, } \\
\text { 2015). }\end{array}$ & $\begin{array}{l}\text { - Create training } \\
\text { goals and } \\
\text { programs, control } \\
\text { training (Hallinger, } \\
\text { 2011). } \\
\text { - Observe and } \\
\text { instruct teachers } \\
\text { (Southworth, } \\
\text { 2002). }\end{array}$ & - \\
\hline
\end{tabular}




\section{Acta Educationis Generalis \\ Volume 10, 2020, Issue 3}

\begin{tabular}{|c|c|c|c|}
\hline $\begin{array}{l}\text { Educator's } \\
\text { activity }\end{array}$ & $\begin{array}{l}\text { - Constant } \\
\text { consistency and } \\
\text { repetition of tasks } \\
\text { (Milner \& } \\
\text { McCarthy 2020). } \\
\text { - Focus on teaching } \\
\text { goals that influence } \\
\text { students' success } \\
\text { (Crocker \& Knight, } \\
\text { 2005). }\end{array}$ & $\begin{array}{l}\text { - Understanding of } \\
\text { learning needs } \\
\text { (Helen \& Printy, } \\
\text { 2003). } \\
\text { - Leading of the } \\
\text { educational process } \\
\text { (Smith \& Andrews, } \\
\text { 1989). } \\
\text { - Monitoring and } \\
\text { improving students' } \\
\text { progress } \\
\text { (Southworth, } \\
\text { 2009). }\end{array}$ & $\begin{array}{l}\text { - Collaboration } \\
\text { with parents and } \\
\text { organizations } \\
\text { (Hajisoteriou, } \\
\text { 2012). }\end{array}$ \\
\hline $\begin{array}{l}\text { Learner's } \\
\text { results }\end{array}$ & $\begin{array}{l}\text { - Students' } \\
\text { assessment results } \\
\text { (Bean et al., 2010). }\end{array}$ & $\begin{array}{l}\text { - Good results (Lee } \\
\text { \& Smith, 1996). }\end{array}$ & $\begin{array}{l}\text { - Achievement of } \\
\text { high results } \\
\text { (Cotton, 2003). }\end{array}$ \\
\hline $\begin{array}{l}\text { Learning } \\
\text { environment }\end{array}$ & - & $\begin{array}{l}\text { Organized, } \\
\text { disciplined, safe } \\
\text { and supportive } \\
\text { educational } \\
\text { environment } \\
\text { (Goldring et al., } \\
\text { 2009). }\end{array}$ & $\begin{array}{l}\text { - Improvisational } \\
\text { and supportive } \\
\text { (Baporikar, } \\
\text { 2018). }\end{array}$ \\
\hline $\begin{array}{l}\text { Relationship in } \\
\text { leadership }\end{array}$ & $\begin{array}{l}\text { - Equivalence, } \\
\text { interconnection } \\
\text { (Robertson, 2008). }\end{array}$ & $\begin{array}{l}\text { Relationship with } \\
\text { students and the } \\
\text { home environment } \\
\text { (Smith \& Andrews, } \\
\text { 1989). }\end{array}$ & $\begin{array}{l}\text { - Collaboration } \\
\text { between } \\
\text { teachers, } \\
\text { students, and } \\
\text { leaders } \\
\text { (Mulford \& } \\
\text { Silins, 2003). }\end{array}$ \\
\hline Teamwork & $\begin{array}{l}\text { Mutual process, } \\
\text { when the leader } \\
\text { influences the } \\
\text { learner, seeks to } \\
\text { advise, develop } \\
\text { knowledge and } \\
\text { skills (Hallinger, } \\
\text { 2007). }\end{array}$ & $\begin{array}{l}\text { - It aims to share a } \\
\text { common vision in } \\
\text { the educational } \\
\text { process by } \\
\text { encouraging } \\
\text { students } \\
\text { (Leithwood \& } \\
\text { Riehl, 2005). }\end{array}$ & - \\
\hline
\end{tabular}




\begin{tabular}{|c|c|c|c|}
\hline $\begin{array}{l}\text { Educator's } \\
\text { professional } \\
\text { development }\end{array}$ & $\begin{array}{l}\text { - The improvement } \\
\text { of professional } \\
\text { activity (Haan et } \\
\text { al., 2010). }\end{array}$ & $\begin{array}{l}\text { - Professional } \\
\text { knowledge and } \\
\text { competence } \\
\text { (Spillane et al., } \\
\text { 2003). } \\
\text { - The improvement } \\
\text { of continuous } \\
\text { knowledge } \\
\text { (Hallinger et al., } \\
\text { 2017). }\end{array}$ & $\begin{array}{l}\text { - The } \\
\text { improvement of } \\
\text { knowledge } \\
\text { (Hart, 1999). }\end{array}$ \\
\hline Advantages & $\begin{array}{l}\text { - Guide the student } \\
\text { towards career } \\
\text { success (Peng et al., } \\
\text { 2019). }\end{array}$ & $\begin{array}{l}\text { Teaching is } \\
\text { student-oriented, } \\
\text { and professional } \\
\text { communities of } \\
\text { teachers are also } \\
\text { formed (York-Barr } \\
\text { \& Duke, 2004). }\end{array}$ & $\begin{array}{l}\text { - Opportunities } \\
\text { are created to } \\
\text { develop the } \\
\text { student's artistic } \\
\text { identity, while } \\
\text { teachers become } \\
\text { learners } \\
\text { (Baporikar, } \\
\text { 2018). } \\
\text { - Share of interest } \\
\text { (Harris, 2008). }\end{array}$ \\
\hline Disadvantages & $\begin{array}{l}\text { - Exceeding of the } \\
\text { content and } \\
\text { pedagogical } \\
\text { knowledge (Knight, } \\
\text { 2007). }\end{array}$ & - & $\begin{array}{l}\text { - Reduction of } \\
\text { knowledge } \\
\text { progress } \\
\text { (Murphy et al., } \\
\text { 1983). }\end{array}$ \\
\hline
\end{tabular}

Goal: The aim of coaching leadership, according to Berg and Karlseno (2007) is directed to help. That means to help the learner improve through the use of an active leader's questionnaire. The active questionnaire helps the learner change learning habits in order to achieve very important educational goals. On the contrary to coaching leadership, the instructional leadership aim is directed to effective education. As reported by Southworth (2009) effective teaching aims to improve the teaching and learning of students. Also in this leadership it is sought to engage the learner in a dialogue which helps recognition of the learner's effective learning and outcomes. Effective training in instructional leadership is modelled, monitored, and advised by management. Meanwhile, the goal of educational leadership is to develop a variety of learner abilities, build learning communities, and pursue learning goals by creating the conditions for distributed leadership (Male \& Palaiologou, 2015).

Educational process: Coaching leadership development is focused on the context of professional practice. That means when two people have a relationship in the process of education in order to achieve common goals. Such 


\section{Acta Educationis Generalis \\ Volume 10, 2020, Issue 3}

education is the most effective when the educator uses a variety of actions: provides new tasks (Robertson, 2008), reviews works, discusses, pays attention to results (Bean et al., 2010) and also effectively maximizes tasks. Meanwhile, the process of instructional leadership development is focused on the emphasis on curriculum and teaching. In accordance with Smith \& Andrews (1989) the curriculum also includes an organized environment and high academic employment, as well as frequent assessment of student progress. However, the process of developing educational leadership, in contrast to coaching and instructional, is characterized by constant attention and a structured learning experience. In order to accumulate knowledge and facilitate the learning process in education, the educator needs to pay attention and systematize the learning experience (Hallinger, 2011; Murphy et al., 2007). Also, in all leadership processes, effective learner training prevails in the educational process (Eriksen et al., 2020).

Manager activity: The leader in coaching leadership requires a systematic nature of ruling activity that is results oriented, with compatibility of human resources. According to Pousa \& Mathieu (2015), dedication to work, building inner confidence, strengthening work, and instruction is very important. At the same time, the activities of the instructional leadership manager are characterized by curriculum management (coordinating the curriculum, monitoring student progress) and promoting a positive environment (protecting teaching time, promoting professional development, encouraging teachers, and promoting learning).

Educator activity: In coaching leadership, the educator's activities are focused on providing constant and consistent tasks to the students and giving attention to achieving the student's goals. Applying tasks and giving attention contribute to the learner's success (Crocker \& Knight, 2005). But unlike coaching leadership, the instructional leadership educator's activity, according to Helen and Printy (2003), is aimed at understanding learning needs, coaching, creating a social and interactive environment, selecting learning knowledge and tasks, and applying methods that promote student motivation. Meanwhile, the activities of the educational leadership educator are focused on such activities as community mobilization, and cooperation with parents (Hajisoteriou, 2012). Also, the activities of this leadership educator are characterized by the ability to lead others, the desire to learn new things constantly and adapt to change.

Learner results: All leadership focuses on student outcomes, but all of them differ. In coaching leadership, the educator focuses on the results of the assessment (Bean et al., 2010). Meanwhile, in instructional leadership, according to Lee and Smith (1996) most attention is paid to good results for which the school community is responsible. Furthermore, educational leadership seeks high results. Cotton (2003) says, in order to achieve high results, parents and other members of community are involved. 


\section{Acta Educationis Generalis \\ Volume 10, 2020, Issue 3}

Learning environment: Goldring et al. (2009), notice that in instructional leadership the learning environment is academic and accurate. Arrangement, discipline and security prevail: in contrast to instructional leadership in educational leadership, the learning environment is free. As Cotton (2003) admits, such an environment creates a supportive and improvisational culture of communication.

Relationship in leadership: In coaching leadership education takes place through partnership. Robertson (2008) explains that this means that both the educator and the teacher engage in the relationship as equals. And this requires daily experience to put the effectiveness of a warm relationship in practice. However, in instructional leadership, in contrast to coaching, relationships are maintained and developed not only with the learner but also with his/her home environment. (Smith \& Andrews, 1989). Meanwhile, in educational leadership, as Mulford and Silins (2003) say, relationships prevail between teachers, students, and school leaders. Such relationships are based on a common feature that includes an atmosphere of trust and cooperation, a shared and controlled mission, and continuous professional development.

Teamwork: Mutual work is important in coaching leadership - both for the educator and the student. Hallinger (2007) claims that leadership must be understood as a process of mutual influence, not as a one-way process in which leaders influence others. In the meantime, in instructional leadership, according to Leithwood and Riehl (2005), teamwork aims to encourage students to pursue a shared vision of goals.

Learner professional development: In coaching leadership, it is important for the educator's professional development to change his/her behavior, but not his/her personal qualities. In this way professional activity and efficiency in organization are improved (Haan et al., 2010). Also, it is essential to improve skills and inner competencies. Meanwhile, both instructional and educational leaderships are characterized by professional development, where the professional knowledge, skills and competences of educators are enhanced (Hart, 1999).

Advantages: In coaching leadership, according to Peng et al. (2019), the student's career predominates. This happens because in this leadership, much attention is paid to the learner providing him/her any help in different situations. Meanwhile, the advantage of instructional leadership is that education is focused on a student's training and the formation of a professional community (YorkBarr \& Duke, 2004). However, unlike coaching and instructional leadership, educational leadership has the following benefits: the pursuit of common educational goals and the development of students' artistic identity. The concept of shared leadership prevails in such leadership (Harris, 2008).

Disadvantages: In coaching leadership, it is observed that applying such a leadership style in education, content and pedagogical boundaries are transcended (programs and attitudes) (Knight, 2007). On the other hand, in 


\section{Acta Educationis Generalis \\ Volume 10, 2020, Issue 3}

educational leadership, as Murphy et al. (1983) claim that the lack of methodological tools does not lead to the acquisition of essential knowledge of progress.

\subsection{Similarities between coaching, instructional, and educational leadership styles}

Scientific analysis of the similarities between coaching, instructional, and educational leadership styles has revealed that each of these styles has criteria such as: factors that determine success in the learning process, learning environment, learning outcomes, feedback, and similar leadership benefits.

\section{Table 2}

Similarities between coaching, instructional, and educational leadership styles

\begin{tabular}{|c|c|c|c|}
\hline Criterion & $\begin{array}{l}\text { Coaching } \\
\text { leadership/Authors }\end{array}$ & $\begin{array}{c}\underline{\text { Instructional }} \\
\text { leadership/Authors }\end{array}$ & $\begin{array}{c}\underline{\text { Educational }} \\
\text { leadership/Authors }\end{array}$ \\
\hline $\begin{array}{l}\text { Factors } \\
\text { determining } \\
\text { success in } \\
\text { the } \\
\text { educational } \\
\text { process }\end{array}$ & $\begin{array}{l}\text { - Growth and change } \\
\text { (Clutterbuck \& } \\
\text { Megginson, 2005). }\end{array}$ & $\begin{array}{l}\text { Cooperation, } \\
\text { professional } \\
\text { development and } \\
\text { promotion of } \\
\text { learning (Urick, } \\
\text { 2016). }\end{array}$ & $\begin{array}{l}\text { - Clear and } \\
\text { effective } \\
\text { communication } \\
\text { and relationship } \\
\text { building skills, } \\
\text { effective design } \\
\text { of educational } \\
\text { process and } \\
\text { promotion of new } \\
\text { perspectives } \\
\text { (McLeod, 2007). }\end{array}$ \\
\hline $\begin{array}{l}\text { Learning } \\
\text { environment }\end{array}$ & $\begin{array}{r}\text { - Positive (Clutterbuck } \\
\quad \text { \& Megginson, 2005). }\end{array}$ & $\begin{array}{l}\text { - } \text { Supportive (Urick \& } \\
\text { Bowers, 2014). }\end{array}$ & $\begin{array}{l}\text { - } \text { Trust and respect } \\
\text { (McLeod, 2007). }\end{array}$ \\
\hline $\begin{array}{l}\text { Learning } \\
\text { process } \\
\text { outcomes }\end{array}$ & 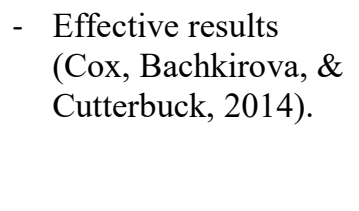 & $\begin{array}{ll}\text { - } & \text { Fast outcomes } \\
& \text { (Shaked, 2019). } \\
\text { - } & \text { Good learning results } \\
\text { (Spillane et al., } \\
\text { 2003). }\end{array}$ & \\
\hline Feedback & $\begin{array}{l}\text { - Feedback and praise } \\
\text { (Berg \& Karlseno, } \\
\text { 2007); } \\
\text { - Repetition of } \\
\text { feedback at a later } \\
\text { time (Harrison, } \\
\text { 2007). }\end{array}$ & 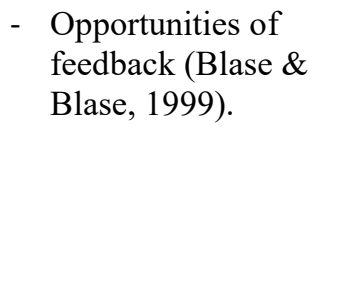 & $\begin{array}{l}\text { - Providing } \\
\text { feedback } \\
\text { (McLeod, 2007). }\end{array}$ \\
\hline
\end{tabular}




\section{Acta Educationis Generalis \\ Volume 10, 2020, Issue 3}

Factors determining educational success: Similar factors prevail in all leadership styles, which determine the success of education, that is: improvement of education, assistance in the educational process, ability to motivate and promote understanding, career growth and change (McLeod, 2007; Urich, 2016).

Learning environment: The same learning environment predominates in coaching, instructional and educational leadership. According to Clutterbuck and Megginson (2005) these environments are characterized by trust, positivity, support and growth in an educational atmosphere. The authors claim that in such an environment, the learner feels good and thus achieves high learning outcomes.

Learning results: Coaching and instructional leadership have high results in the educational process. A strong school community is responsible for these results of leadership (Lee \& Smith, 1996; Spillane et al., 2003). Shaked (2019) says that using coaching and instructional leadership it is possible to improve and achieve the same learning outcomes much faster.

Feedback: In the educational process, using coaching, instructional and educational leadership, feedback to the learner dominates. According to Berg and Karlsen (2007) through feedback, the student is given praise, remarks and improvements in education. As Harrison and Knight (2007) declare, in applying the types of leadership the student is observed in a certain activity and this results in providing comments about what is being done well and what needs to be improved.

\section{Conclusion}

Every type of leadership is specific and has its own particular features, distinguishing the differences and similarities that prevail in them. Coaching leadership is characterized by the help given by the educator to the learner, and understanding and warm relationships between them in the educational process, which determine further career success. Instructive leadership is based on the development of interrelations not only with the learner, but also with the learner's environment, the educator's guidance in the educational process, effective teaching and the pursuit of high results. Finally, educational leadership is distinguished by common work, the pursuit of common goals between the educator and the student, and the process of sharing education. Meanwhile, according to the similarity parameters (criteria), the analyzed leadership styles are characterized by good communication skills, development, motivation, positive learning environment, the pursuit of high results, and the provision of feedback. These similarities come out in the factors of educational process which determine success, learning environment, feedback, learning results and benefits. 


\section{Acta Educationis Generalis \\ Volume 10, 2020, Issue 3}

\section{References}

Baporikar, N. (2018). Educational leadership for quality teacher education in the digital era. In Handbook of Research on Educational Planning and Policy Analysis (pp. 241-255). Port Harcourt: Pearl Publishers.

Blase, J., \& Blase, J. (1999). Principals' instructional leadership and teacher development: Teachers' perspectives. Educational Administration Quarterly, 35(3), 349-378. https://doi.org/10.1177/0013161X99353003

Bean, R. M., Draper, J. A., Hall, V., Vandermolen, J., \& Zigmond, N. (2010). Coaches and coaching in reading first schools: a reality check. The Elementary School Journal, 111(1), 87-114. Retrieved from https://www.jstor.org/stable/10.1086/653471

Berg, M. E., \& Karlsen, J. T. (2007). Mental models in project management coaching. Engineering Management Journal, 19(3), 31-41. https://doi.org/10.1080/10429247.2007.11431736

Bachkirova, T., Cox, E., \& Cutterbuck, D. (2014). Introduction. In E. Cox, T. Bachkirova, \& D. Cutterbuck (Eds.), The Complete Handbook of Coaching (pp. 1-18). London: Sage Publications.

Chen, T. T. (2016). An inclusion comparison approach for multiple criteria decision analysis based on interval-valued intuitionistic fuzzy sets. Technological and Economic Development of Economy, 22(3), 357-392. https://doi.org/10.3846/20294913.2014.989930

Clutterbuck, D., \& Megginson, D. (2005). Making Coaching Work, Creating a Coaching Culture. London: Charted Institute of Personnel and Development.

Crocker, J., \& Knight, K. M. (2005). Contingencies of self-worth. Current Directions in Psychological Science, 14(4), 200-203. https://doi.org/ 10.1111/j.0963-7214.2005.00364.x

Cotton, K. (2003). Principals and Student Achievement: What Research Says. Alexandria, VA: Association for Supervision and Curriculum Development.

Eriksen, M., Collins, S., Finocchio, B., \& Oakley, J. (2020). Developing students' coaching ability through peer coaching. Journal of Management Education, 44(1), 9-38. https://doi.org/10.1177/1052562919858645

Goldring, E., Porter, A., Murphy, J., Elliott, S. N., \& Cravens, X. (2009). Assessing learning-centered leadership: connections to research, professional standards, and current practices. Leadership and Policy in Schools, 8(1), 1-36. https://doi.org/10.1080/15700760802014951

Harris, A. (2005). Leading from the chalk-face: an overview of school leadership. Leadership, 1(1), 73-87. https://doi.org/10.1177/ 1742715005049352

Hallinger, P. (2007). Research on the practice of instructional and transformational leadership: Retrospect and prospect. Paper presented at the ACER Research Conference, Australia. Retrieved from 


\section{Acta Educationis Generalis \\ Volume 10, 2020, Issue 3}

https://research.acer.edu.au/cgi/viewcontent.cgi?article $=1004 \&$ context $=$ rese arch conference 2007

Haan, D. E., Bertie, C., Day, A., \& Sills, C. (2010). Clients' critical moments of coaching: Toward a "client model" of executive coaching. Journal of Academy of Management Learning \& Education, 9(4), 607-621. https://doi.org/https://doi.org/10.5465/amle.9.4.zqr607

Helen, M. M., \& Printy, S. M. (2003). Principal leadership and school performance: An integration of transformational and instructional leadership. Educational Administration Quarterly, 39(3), 370-397. https://doi.org/10.1177\%2F0013161X03253412

Hallinger, P. (2011). Leadership for learning: lessons from 40 years of empirical research. Journal of Educational Administration, 49(2), 125-142. https://doi.org/10.1108/09578231111116699

Hallinger, P., Liu, S., \& Piyaman, P. (2017). Does principal leadership make a difference in teacher professional learning? A comparative study China and Thailand. Compare: A Journal of Comparative and International Education, 49(3), 341-357. https://doi.org/10.1080/03057925.2017. 1407237

Harris, A. (2008). Distributed leadership according to the evidence. Journal of Educational Administration, 46(2), 172-188. https://doi.org/10.1108/ 09578230810863253

Hart, A. W. (1999). Educational leadership: a field of inquiry and practice. Educational Management \& Administration, 27(3), 323-334. https://doi.org/10.1177/0263211X990273008

York-Barr, J., \& Duke, K. (2004). What do we know about teacher leadership? Findings from two decades of scholarship. Review of Educational Research, 74(3), 255-316. https://doi.org/10.3102/00346543074003255

Knight, J. (2007). Instructional Coaching: A Partnership Approach to Improving Instruction. Thousand Oaks, CA: Corwin.

Leech, N. L., \& Onwuegbuzie, A. J. (2008). Qualitative data analysis: A compendium of techniques and a framework for selection for school psychology research and beyond. School Psychology Quarterly, 23(4), 587604. http://dx.doi.org/10.1037/1045-3830.23.4.587

Leithwood, K., \& Riehl, C. (2005). What do we already know about educational leadership? In W. A. Firestone \& C. Riehl (Eds.), A New Agenda for Research in Educational Leadership (pp. 12-27). New York, NY: Teachers College Press.

Louis, K. S., Leithwood, K., Wahlstrom, K., \& Anderson, S. (2010). Investigating the links to improved student learning: Final report of research findings. St. Paul, MN: Center of Applied Research and Educational Improvement.

Lee, V. E., \& Smith, J. B. (1996). Collective responsibility for learning and its effects on gains in achievement for early secondary school students. 
American Journal of Education, 104(2), 103-147. https://doi.org/ $10.1086 / 444122$

Male, T., \& Palaiologou, I. (2015). Pedagogical leadership in the 21st century: Evidence from the field. Educational Management, Administration \& Leadership, 43(2), 214-231. https://doi.org/10.1177/1741143213494889

Marks, H. M., \& Printy, S. M. (2003). Principal leadership and school performance: An integration of transformational and instructional leadership. Educational Administration Quarterly, 39(3), 370-397. https://doi.org/10.1177/0013161X03253412

Miethe, T. D., \& Drass, K. A. (1999). Exploring the social context of instrumental and expressive homicides: An application of qualitative comparative analysis. Journal of Quantitative Criminology, 15(1), 1-21. http://dx.doi.org/10.1023/A:1007550704282

Milner, J., Trenton Milner, T., \& McCarthy, G. (2020). A coaching culture definition: An industry-based perspective from managers as coaches. The Journal of Applied Behavioral Science, 56(2), 237-254. https://doi.org/ 10.1177/0021886320905126

McLeod, A. (2007). Self-Coaching Leadership: Simple Steps from Manager to Leader. Chichester: John Wiley \& Sons.

Mulford, B., \& Silins, H. (2003). Leadership for organisational learning and improved student outcomes - What do we know? Cambridge Journal of Education, 33(2), 175-195. https://doi.org/10.1080/03057640302041

Murphy, J., Hallinger, P., \& Mitman, A. (1983). Problems with research on educational leadership: Issues to be addressed. Educational Evaluation and Policy Analysis, 5(3), 297-305. https://doi.org/10.3102/ 01623737005003297

Murphy, J., Vriesenga, M., \& Storey, V. (2007). Educational administration quarterly 1979-2003: An analysis of types of work, methods of investigation, and influences. Educational Administration Quarterly, 43(5), 612-628. https://doi.org/10.1177/0013161X07307796

Pousa, C., \& Mathieu, A. (2015). Is managerial coaching a source of competitive advantage? Promoting employee self-regulation through coaching. Coaching: An International Journal of Theory, Research and Practice, 8(1), 20-35. https://doi.org/10.1080/17521882.2015.1009134

Peng, Z., Gao, B., \& Zhao, H. (2019). Coaching leadership and subordinates' career success: The mediating role of leader-member exchange. Social Behavior and Personality: An international journal, 47(11), e8406. https://doi.org/10.2224/sbp.8406

Robertson, J. (2008). Coaching Educational Leadership. Building Leadership Capacity Through Partnership. Los Angeles: Sage.

Southworth, G. (2002). Instructional leadership in schools: Reflections and empirical evidence. School Leadership \& Management, 22(1), 73-91. https://doi.org/10.1080/13632430220143042 
Smith, W., \& Andrews, R. (1989). Instructional Leadership: How Principals Make a Difference. Alexandria, VA: Association for Supervision and Curriculum Development.

Southworth, G. (2009). Learning-centered leadership. In B. Davies (Ed.), The Essentials of School Leadership (pp. 91-111). London: SAGE.

Spillane, J. P., Diamond, J. B., \& Jita, L. (2003). Leading instruction: The distribution of leadership for instruction. Journal of Curriculum Studies, 35(5), 533-543. https://doi.org/10.1080/0022027021000041972

Shaked, H. (2019). Social Justice Leadership, Instructional Leadership, and The Goals of Schooling. Netivot, Israel: Hemdat Hadarom College of Education. Retrieved from https://haimshaked.com/wp-content/uploads/ 2019/08/pdf-1.pdf

Talalienè, Ž., \& Šečkuvienè, H. (2015). Muzikos mokytojo lyderystès gebejjimų raiška. Pedagogika, 119(3), 134-146.

Turner, P. S. (2010). Aligning Organisational Coaching with Leadership Behaviour (Doctoral thesis). Birmingham City University. Retrieved from http://www.open-access.bcu.ac.uk/4908/1/2010_Turner_533142.pdf

Urick, A. (2016). Examining US principal perception of multiple leadership styles used to practice shared instructional leadership. Journal of Educational Administration, 54(2), 152-172. https://doi.org/10.1108/JEA07-2014-0088

Urick, A., \& Bowers, A. J. (2014). What are the different types of principals across the United States? A latent class analysis of principal perception of leadership. Educational Administration Quarterly, 50(1), 96-134. https://doi.org/10.1177/0013161X13489019 